\title{
The Implementation of Inclusive Education Program for Early Childhood
}

\author{
Putu Rahayu Ujianti ${ }^{1 *}$
}

\author{
${ }^{1}$ Universitas Pendidikan Ganesha, Indonesia \\ *Corresponding author. Email: puturahayuujianti@undiksha.ac.id
}

\begin{abstract}
It is understood and stated by the law that every child has a right to access education. It is even more important for young children to enroll in early childhood education programs to get stimulation as early as possible for their growth and development. The inclusive program became the answer for children whose access was limited to special need school. The purpose of this article is to describe the implementation of inclusive education programs in early childhood (early childhood education programs). The research was conducted at two kindergartens in Singaraja, Bali, between January-March 2020. This research used a qualitative approach to assist with the study case method. The data collection techniques used were interview, observation, and documentation. Data analysis techniques of the research used interactive models by Miles and Huberman. The result showed that (1) not all teachers are familiar with the concept of inclusion; (2) however teachers showed a positive attitude toward students with special need; (3) the learning which designed based on the need of special children were limited; (4) teachers need support to enhance their skill to do early detection and create the appropriate learning and approach for children with special need in their class; (6) the facility to support special need children in school is very limited.
\end{abstract}

Keywords: Early Childhood Education Program, Inclusive Education, Special Need Children

\section{INTRODUCTION}

According to [1], in the chapter 4 verse 1 , it is stated that education is carried out democratically, with justice, and not discriminative, also it must be highly appreciating the human rights, religious and cultural values, and the diversity of the nation. This statement emphasizes the equal redistribution of the rights and responsibilities for every Indonesian citizen to access education. On the other hand, the status quo seems to show that more children than we expected cannot access education, especially when we talk about special needs ones.

The data shows that the total amount of Indonesian special needs students year 2017/2018 reached the number of 128.721 (www.lokadata.co.id). Specifically, the total amount of special needs citizens in Bali reached 3,4 millions of people. The data from Statistics Indonesia (known as Badan Pusat Statistik (BPS)) year 2018 shows that only $5,48 \%$ of the disabled citizens are still going to school, meanwhile, $23,91 \%$ are not. The data implies that so many special needs children are not able to get qualified education based on government policy. One of the factors is the lack of existence of an inclusive school that accommodates them.

Children with special needs are the ones who need special treatments because they have different characteristics [2]. Their struggles make them craving for special needs education treatment based on the competency and potencies. The earlier the special need symptoms are detected, the quicker the children will get the exact treatment. In this case, the presence of early childhood institutions is urgently and crucially needed, especially in Buleleng Regency. There is no option for special need kindergarten which makes the special need children must go to the regular school to socialize and to be stimulated. This is the reason why the early childhood institution or kindergarten needs to prepare to implement inclusive education.

Inclusive education is a practice that educates all students, especially the ones who face struggles and development problems [3]. Inclusive education is a form of responsibility implementation as stated in chapter 31 of [4], that is every citizen has the right to get an education. This is emphasized in the quotation of [5] about inclusive education which states that the chance to 
get qualified education based on the needs and abilities given to the students which have physical, emotional, mental, and social disabilities or the ones who are gifted and have special talents.

States that inclusive education is a program that accommodates children without seeing on the physical, intellectual, social, emotional, language, and any other circumstances of them [6]. Inside the inclusive education program, the diversity of the students are embraced by increasing the students' participation in the learning process with the assumption that life and learning together is the best way in handling diversity.

In Bali, especially in Buleleng Regency, the inclusive institutions are still limited thus the services for the special needs are limited as well. The citizen still thinks that special needs schools (known as SLB) are the only places for disabled students to learn. The problem is, the distribution of SLB in Buleleng Regency is limited, only in Singaraja. From all institutions that exist, there is no special need school for kindergarten (known as TKLB (Taman Kanak-Kanak Luar Biasa)). Even if the early childhood phase is where the children are developing and growing up fast compared with the other development phase.

The preliminary study shows that some kindergarten schools in Buleleng accept special needs students, such as, TK Rare Bali School which is located in Singaraja, and TK Negeri Banyuseri which is located in Banjar. The special needs children who go to both schools learn together, in the same classes with the other students. The students' special needs are such Down Syndrome, Asperger Syndrome, and Attention Deficit Hyperactivity and Impulsivity (ADHD).

Inclusive education is including two components; action planning and implementation [7]. The implementation of inclusive education is including curriculum modification, educators (teachers), students, facilities, finances, and the environment. Besides, the implementation of inclusive education is including learning activities, building bonds between individuals, and implementation evaluation of inclusive education. Inclusive education components are stated in [8] which covers, curriculum management, student management, teachers management, facilities management, financial management, environment management, special service management, and evaluation management.

\section{METHODS}

This is a descriptive qualitative research. It aimed to picture the implementation of inclusive education in kindergarten in Bali. The implementation of inclusive education here covers two aspects, which is the planning and the implementation. The subject of the research was the inclusive education implementation in TK Rare Bali School and TK Negeri Banyuseri. The respondents of the research were the headmaster the teachers of the schools. Both the kindergartens were chosen because they accept the children with special needs to study together with regular children. The data was gained in Januari-Maret of 2020 .

The aspects analyzed are (1) the teachers understanding about inclusive education, (2) the planning and implementation of inclusive education in both kindergartens which covers the curriculum, education, students, parents, facilities, and the learning activities at class, (3) the support and help which are ne

The data analysis of the research used [9] that has three phases, which are, data reduction, data display, and verification and conclusion drawing.

\section{RESULTS AND DISCUSSION}

The inclusive education implementation in the kindergartens in Bali can be pictured as followed:

1. The kindergarten which becomes the research subjects are not formally stating themselves as the inclusive institutions, yet, accept the special needs students to study there. In the vision and mission of both the kindergartens, it is not stated about inclusive education.

2. Teachers do not fully understand the system of inclusive education, just hearing the concept without having deep research about it. But, they are openly accepting the special needs students with the nonspecial needs students in the class.

3. TK Rare Bali School and TK Negeri Banyuseri use the same curriculum which is known as the 2013 Curriculum or Kurikulum 2013 which is modified based on the development phase, needs, and students interest. It is found out that there is an existence of aims, materials, and purposes adjustment based on the students' need. There is a no different template of curriculum between the special needs children and the non-special needs children, but in the implementation of learning activities, the teachers adjust based on the students' ability, in the materials and the assessments. [3] argues that the curriculum used in inclusive education can be the one that the regular students usually use, but modified based on the previous abilities and students' characteristics. Furthermore, based on [10] the general school curriculum which is used for special needs children is modified by omitting the basic competency, learning methodology, and learning outcomes evaluation. The adjustments can help to ease the students especially the special needs students to understand the learning materials. Even though the curriculum has been adjusted and modified, TK Rare Bali School and TK Negeri Banyuseri have not used Individualized Education Programme (IEP). TK Rare Bali School 
and TK Negeri Banyuseri teachers gained special needs students' insight through workshops. Based on the operational basic procedure of the inclusive Early Childhoodcation [11], the teachers' professional development is crucial, so the teachers have a positive attitude and are expected to have effective treatments for special needs students. TK Rare Bali School has a main teacher, a helper teacher, and a special assistant teacher (known as shadow teacher or GPK (Guru Pendamping Khusus)). The schools can only use the shadow teacher if the special needs students need special treatments. The GPK recruitment is based on the requirement which is the GPK teacher must have the academic qualification and special education competencies. The teacher then is chosen by the school to help the implementation of the inclusive program at the regular school [12]. Meanwhile in because of the limited condition of human resources, TK Negeri Banyuseri has no GPK yet. Even if the constant training related to special needs students have been given, the complaints of the teachers related to the special needs students were still found.

4. TK Negeri Banyuseri and TK Rare Bali School accept special needs students in their institutions. The difference was found in the system of the registration. In TK Rare Bali School, the prospective students who have special needs are identified in the registration phase. It is different from the TK Negeri Banyuseri where the school does not implement the same registration system. The schools which implement inclusive education need to consider the resources owned by the school, such as paying attention to the capacity and the strength of the school [13].

5. The students' parents are supportive of the programs which have been arranged and planned by the schools. The supports are given because the schools are always engaging the parents in the planning meetings of the school's programs. As argued by [14], without the support from the parents, the students will face difficulties in gaining achievements because of the lack of confidence. Meanwhile, because of its location in the rural area, with the parents' background which has lack insight about special needs children and the inclusive education, the teachers in TK Negeri Banyuseri must work hard to get supports and cooperation from the parents. The teachers regularly conducted home visits to intensively communicate with the parents. Stated that professional collaboration is needed due to effective teaching in inclusive class, which is cooperating with the parents in the learning system [15].

6. The facility is the most important factor which determines the victory of inclusive education implementation [16]. There are no special facilities destined for the disabled children or the special needs students in TK Rare Bali School and TK Negeri
Banyuseri. The facilities are the common ones. The lack of financial allocation availability is the main cause.

7. In general, the implementation of the learning process of special needs and the regular students is conducted in one class. Some of the special needs students need special supervision when doing activities outside the room, to ensure the students' safety. Students are motivated to be fully spirited in joining every activity [17].

8. [17] said that inclusive learning evaluation characteristic on the regular class is by observation. It is also found in the students' evaluation at TK Rare Bali School and TK Negeri Banyuseri is done through observation. The evaluation is carried out every day and every semester. The evaluation is in form of anecdote notes, daily development scale, and work notes. Teachers will evaluate the students' development while the learning process is conducted. The assessment process for special needs children is differentiated from the non-special needs children. The adjustment of the tasks and exercises for the special needs students assessment is needed [12]. The form of learning outcomes report of the special needs students is the same as the regular students, but the standard and the passing grade is different where the passing grade for the special needs students is lower [18]. The result of the students' mark will be used as an effort to increase the development aspect which is classified as lower than the learning objectives.

\section{CONCLUSION}

The study identified four main challenges of the online learning conducted by boomers during Covid-19 Outbreak in Indonesia. The challenges range from the participants' ICT skill, internet connection, time management, and students' accessibility to the online learning. The study also found that although boomers have positive beliefs about online learning during this crisis situation, they still prefer direct interaction in classroom to teach. Moreover, considering the lack of ICT skills that they possess, boomers expected training on ICT tools for their future teaching. These findings imply that improvement in personal quality in conducting online learning is needed through several training. Future research might be directed to evaluate the effectiveness of ICT Tools used by boomers in their online learning activity.

\section{REFERENCES}

[1] Undang-Undang Republik Indonesia Nomor 20 Tahun 2003.

[2] M. A. Ambarsari, Mengenal ABK (Anak Berkebutuhan Khusus), Surabaya: Biro Psikologi Aktualitta, 2014. 
[3] Tarmansyah, Inklusi Pendidikan untuk Semua. Jakarta: Depdiknas, 2007.

[4] Undang-Undang Dasar Republik Indonesia, 1945.

[5] Permendikbud tentang Pendidikan Inklusif, 2009.

[6] The Salamanca Statement and Framework for Action on Special Need Education, 1999.

[7] A. Nugroho and L. Mareza, Model Dan Strategi Pembelajaran Anak Berkebutuhan Khusus Dalam" Jurnal Pendidikan Dasar PerKhasa Volume 2, Nomor 2, Oktober 2016, vol. 2, 2016. DOI: https://doi.org/10.31932/jpdp.v2i2.105

[8] S. Sumarni, Pengelolaan Pendidikan Inklusif di Madrasah, EDUKASI J. Penelit. Pendidik. Agama dan Keagamaan, vol. 17, no. 2, 2019, pp. 148-161. DOI: 10.32729/edukasi.v17i2.631.

[9] M. Miles, M. B., \& Huberman, Qualitative Data Analysis Second Edition, SAGE Publications, 1994.

[10] M. Fajra, N. Jalinus, J. Jama, O. Dakhi, U. E. Sakti, and U. N. Padang, Pengembangan Model Kurikulum Sekolah Inklusi $2020 . \quad$ DOI: https://doi.org/10.33830/jp.v21i1.746.2020

[11] K. Pendidikan, D. A. N. Kebudayaan, and F. I. Pendidikan, Kementerian pendidikan dan kebudayaan," vol. 31372, no. 0362, p. 81116.

[12]D. Kustawan, Pendidikan Inklusif \& Upaya Implementasinya, Jakarta: Luxima Metro Media, 2012.

[13]I. Setianingsih, Eka Sari; Listyarini, Implementasi Pelaksanaan Pendidikan Inklusi di SD Bina Harapan Semarang, J. Taman Cendikia, vol. 3, no. 01, 2019, pp. 257-268, DOI: http://dx.doi.org/10.30738/tc.v3i1.2980.

[14]M. Tanjung, Bunga Shashilya; Iswari, Dukungan Orang Tua Terhadap Prestasi Anak Tunanetra di Sekolah Inklusi, J. Pendidik. Inklusi, vol. 3, no. 1, 2019, pp. 040-047, [Online]. DOI: http://dx.doi.org/10.26740/inklusi.v3n1.p40-47 .

[15] G. S. Morrison, Dasar-dasar Pendidikan Anak Usia Dini (PAUD) (Terjemahan Suci Romadhona dan Apri Widiastuti), Jakarta: PT. Indeks, 2012.

[16] M. T. Ilahi, Pendidikan inklusif:konsep dan aplikasi, Yogyakarta: Ar-Ruzz Media, 2016.

[17]L. K. Marthan, Manajemen Pendidikan Inklusif. Jakarta: Depdiknas, 2007.

[18]A. Saputra, Kebijakan Pemerintah Terhadap Pendidikan Inklusif," Golden Age J. Ilm. Tumbuh Kembang Anak Usia Dini, vol. 1, no. 3, 2016, pp. 1-
14. Available at http://ejournal.uinsuka.ac.id/tarbiyah/index.php/goldenage/article/vie w/1929 